\title{
Selection of Tourism Destinations Priority using 6AsTD Framework and TOPSIS
}

\author{
$1^{\text {st }}$ Yunifa Miftachul Arif \\ Department of Electrical Engineering \\ Institut Teknologi Sepuluh November \\ Surabaya, Indonesia \\ Department of Informatics Engineering \\ Universitas Islam Negeri Maulana \\ Malik Ibrahim \\ Malang, Indonesia \\ yunif4@gmail.com
}

\author{
$2^{\text {nd }}$ Supeno Mardi Susiki Nugroho \\ Department of Electrical Engineering \\ Institut Teknologi Sepuluh November \\ Surabaya, Indonesia \\ mardi@ee.its.ac.id
}

\author{
$3^{\text {rd }}$ Mochamad Hariadi \\ Department of Electrical Engineering \\ Institut Teknologi Sepuluh November \\ Surabaya, Indonesia \\ mochar@ee.its.ac.id
}

\begin{abstract}
Many tourist cities in developing countries, especially in Indonesia, have exciting tourism destinations. However, some of them do not use a good management concept, for example, to develop tourism destinations. Early process in the development of the destination is making priority selection appropriately. They should consider the success level of tourism destinations. This paper discusses implementations of the 6AsTD framework and TOPSIS method as a combination concept to select destinations priority that recommended to do development. 6AsTD has six components that reflect successful tourism destinations. All components used in the process of the TOPSIS method as input criteria. This research used 11 tourism destinations data bundles in Batu City. The result is a tourism destination with the highest priority has a score of $\mathbf{0 . 8 8}$, and the lowest priority has a score of 0.19 .
\end{abstract}

Keywords-tourism destinations, development, priority, 6AsTD framework, TOPSIS

\section{INTRODUCTION}

Indonesia is a developing country that has many cities with potential tourism destinations. Some of them are not yet applying the tourism management concept correctly. That is the reason why the tourist and government unable to collect more potential revenue from the tourism sector. Tourism destinations are areas that have a significant influence on improving the economy in tourism cities. If tourism is well developed, then the economy will also run well [1]. Therefore tourist city needs to implement the concept of good tourism development, for example using smart tourism.

Before those concepts implemented and the development process began, the city government should do two things. First, the government must ensure that facilities and services in tourism destinations are available either. We can see the success of tourism destinations through the availability of existing support facilities and service [2]. The development of a tourism destination is carried out by improving the facilities and services [3]. Improving the facilities in a balanced manner is aimed to fulfil the tourist's desires and create comfort for them, so they will be interested in visiting and coming back again [4]. The second is to select the priority destinations base on its characteristics. Each tourism destination certainly has different characteristics regarding facilities and services [5]. The problem is how the city government select tourist destinations priorities appropriately. The developing destinations process will be able to absorb the budget properly if the government does the priority determination correctly.
To answer these problems required a framework and method for analyzing and selecting tourism destinations. There are only a few of the framework that is used to analyze tourism destinations. Among them are the Premier-Ranked Tourist Destination Framework (PRTDF) and 6As of Tourism Destinations (6AsTD) Framework [6][7]. Between two such frameworks, 6AsTD has a complete analysis of the facilities and services in a tourism destination. 6AsTD also specifically used to measure the success level of a tourism destination. This framework consists of six components, which include Attractions, Accessibility, Amenities, Available Packages, Activities and Ancillary Services. Each of these components has different characteristics. Attraction, Available Packages, and Activities generally describe the existing tourism services. Whereas Accessibility, Amenities, and Ancillary Services describe the supporting facilities provided in tourism destinations and surrounding areas [8].

This research proposes a combination of the 6AsTD and Technique for Order Preference by Similarly to Ideal Solution (TOPSIS). We chose this framework and method because both are combinations that complement each other. 6AsTD is in charge of providing the criteria based on the components, whereas TOPSIS served to process these criteria to become a priority. TOPSIS is one of the techniques in multiple-criteria decision-making that can solve the problems with several attributes clearly and systematically [9][10]. TOPSIS is useful for solving complex problems in an operating system [11]. In this research, TOPSIS used to select the tourism destinations that are a priority development. For testing the accuracy of our proposed concept, this research use 11 tourism destinations data bundles in Batu City.

This paper has several sections to describe the research steps and explain the results. The section includes the Framework and Method, Result and Discussion, and the last is Conclusion.

\section{METHOD AND FRAMEWORK}

\section{A. The Tourism Destinations Concept}

The following are definitions that can explain what tourism destinations are. According to Carlos Lampus, a tourism destination is a place that draws the attention of tourists to make tourist visits [12]. It is a fusion of tourism products and services that considered a complex system [13]. Tourism destination is also an area chosen by visitors to carry out tourism activities, covering all available facilities, including entertainment facilities, accommodation, lodging, restaurants, and so on [7][2]. 
Every visitor has a variety of goals when they are at tourism destinations. These goals include refreshing, working, attending activities, shopping, studying or just visiting friends [12]. Therefore, existing facilities and services, including public facilities, must be able to support every visitor activity [13]. For example, tourists certainly need accommodation when they visit a place for more than 24 hours. The tourists also want devices or transportation routes that are easily accessible [14]. Facilities and services included in tourism destinations are accommodation facilities, destination utilities, communication facilities, and destination accessibility. The references to the analysis of accommodation facilities include quality, variety, upmarket and value for money. Destination utilities include clean water and electricity. Communication facilities include modern communication facilities and internet access. Destination accessibility includes quality of the road, traffic congestion, car rental facilities, adequate transport network, adequate internal transportation dan accessibility of attraction sites [14]. We use the parts of tourism destination support services as a reference to complete the variables of the 6AsTD framework described in the next section.

\section{B. 6AsTD Framework}

As stated earlier, each tourist destination has different characteristics even though it located in a nearby city. So the government needs a reference for determining the success rate assessment of a tourist destination. 6AsTD is a framework that can be used to answer these problems. This framework, first introduced by Dimitrios Buhalis, has six main components, shown in figure 1 [7][8][2]. Each component of 6AsTD has different variables. All of them indicate the characteristics of tourism destinations [15].

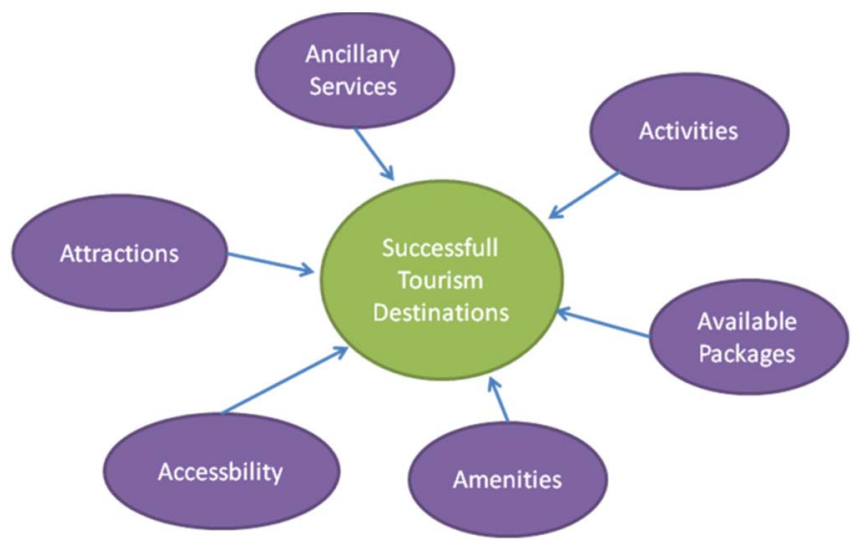

Figure 1: Components of the 6AsTD framework

Attractions are an exciting point in tourist destinations that make people interested in visiting. Tourist attractions are open to the public and use for entertainment, attraction or learning [16]. In this framework, attractions $(A 1)$ have four variables include natural landscape $\left(A 1_{1}\right)$, artificial tourism $\left(A 1_{2}\right)$, cultural tourism $\left(A 1_{3}\right)$ and special events $\left(A 1_{4}\right)$ [7][8][2]. Each of these variables describes the point of interest numbers at each tourism destinations. The following formula is used to get the attraction's score.

$$
A 1=A 1_{1}+A 1_{2}+A 1_{3}+A 1_{4}
$$

Every tourism destinations must have good access to make it easier for visitors to come and doing tourism activities in that place [17]. The accessibility component (A2) has four assessment variables. These variables include transportation routes $\left(A 2_{1}\right)$, terminals $\left(A 2_{3}\right)$, Public
Transportation Inside $\left(A 2_{3}\right)$ and Public Transportation Outside $\left(A 2_{4}\right)$ [4] [5] [6] [15] [16]. Transportation routes are the route available from the city centre to the destination. The terminal variable is about distance access from the terminal to the destination. Public Transportation Inside shows the availability of public transportation at tourism destinations. While Public Transportation Outside shows the alternative transportation that can be used to go to tourism destinations, such as taxis, car rental facilities, buses and other public transportation such as Gojek, Grab, and others. We can get the scores of accessibility components using the following formula.

$$
A 2=A 2_{1}+A 2_{2}+A 2_{3}+A 2_{4}
$$

Amenities are components of the 6AsTD framework that represent available facilities at the tourism destinations. These facilities can be available both inside and surround it [2]. Amenities (A3) have four variables that have a direct influence on visitors. These components can increase the comfort level of visitors. These variables include lodging and hotels $\left(A 3_{1}\right)$, restaurants $\left(A 3_{2}\right)$, public facilities $\left(A 3_{3}\right)$ and shopping centers $\left(A 3_{4}\right)[7][8][14][16]$. Lodging and hotels describe the availability of places used by visitors to stay overnight. Restaurants describe the availability of places for eating. Public facilities include worship facilities, toilets, and so on. A shopping center is a place that can be visited by tourists to buy souvenirs. The following formula is used to get the amenities score.

$$
A 3=A 3_{1}+A 3_{2}+A 3_{3}+A 3_{4}
$$

The available packages component shows a combination of several services in one tour package to offer to visitors [16]. Available packages contain unique offers that can attract visitors' attention [2]. The tour package can be in the form of a package of several tourist spots with special prices. The available packages include guiding services, organized tour packages and special interest tours [15]. The scores of available packages $(A 4)$ is the number of all packages offered to the visitors of a tourism destination.

Activities are components that describe all tourism activities that can be carried out by visitors at tourism destinations. Components of activities affect to trigger tourists to come and visit [8][2]. Each tourism destination may have various activities offered to visitors. These activities example are sightseeing, swimming, outbound, playing, taking photographs, and other activities. The scores of activities component (A5) is the number of all activities that allow visitors to do at a tourism destination.

The ancillary service component describes the supporting facilities inside and around tourism destinations. These facilities may not be directly related to tourism activities but by some visitors need them [2]. Ancillary services (AO) have several variables of assessment; communication channels $\left(A \sigma_{1}\right)$, internet services $\left(A 6_{2}\right)$, ATM or bank $\left(A 6_{3}\right)$, medical services $\left(A 6_{4}\right)$, and postal services $\left(A 6_{5}\right)$ [7][8][14][16]. Communication channels are a means of communication used in tourism destinations, including public telephone and communication technology, that can be accessed by mobile phones. Internet services include public internet services and internet technology through providers that can be accessed using a smartphone. ATM or bank is a supporting facility that allows visitors to access their financial. Medical service variables describe health services and facilities that accessed inside and around tourism destinations. Postal service is a 
facility that does not always exist in tourist attractions but sometimes is needed, for example, to send letters and packages. We use this formula to get the ancillary services score.

$$
A 6=A 6_{1}+A 6_{2}+A 6_{3}+A 6_{4}+A 6_{5}
$$

\section{TOPSIS}

In this research, the Technique for Order Preference by Similarly to Ideal Solution (TOPSIS) is an essential part of the process of determining the priorities of which tourist destinations that are most suitable for development. TOPSIS is one of MCDM techniques used in decision-making methods[11][17]. This technique is a favorite because it has a reasonable concept, easy understanding, and a lighter computing process. The working principle of TOPSIS is that the chosen alternative has the closest distance-vector the positive ideal solution, and the farthest to the negative ideal solution [18]. The following is the TOPSIS procedure used in this study [19][20]:

- Make a normalization of the decision matrix.

$$
r_{i j}=\frac{x_{i j}}{\sqrt{\sum_{i=1}^{m} x^{2}{ }_{i j}}}
$$

- $\quad$ Make a weighted normalized decision matrix.

$$
y_{i j}=w_{i} r_{i j}
$$

- Determine the matrix of positive ideal solutions $\left(A^{+}\right)$and negative ideal solutions $\left(A^{-}\right)$.

$$
\begin{aligned}
& A^{+}=\left(y_{1}{ }^{+}, y_{2}{ }^{+}, \ldots, y_{n}{ }^{+}\right) \\
& A^{-}=\left(y_{1}{ }^{-}, y_{2}{ }^{-}, \ldots, y_{n}{ }^{-}\right)
\end{aligned}
$$

- Determine the distance between scores with the matrix of positive and negative ideal solutions.

$$
\begin{gathered}
D_{1}^{+}=\sqrt{\sum_{j=1}^{n}\left(y_{i}^{+}-y_{i j}\right)^{2}} \\
D_{1}^{-}=\sqrt{\sum_{j=1}^{n}\left(y_{i j-} y_{i}^{-}\right)^{2}}
\end{gathered}
$$

- Determine the preference score for each alternative $\left(V_{\mathrm{i}}\right)$.

$$
V_{i}=\frac{D_{i}^{-}}{D_{i}^{-}+D_{i}^{+}}
$$

There are several parts which are prepared to complete this method, including:

\section{1) Alternative}

The alternative in this study are several choices of objects to be processed; they are tourism destinations with the lowest score.

\section{2) Criteria}

Criteria are the characteristics possessed by the tourism destinations object. These characteristics have obtained the component of the 6AsTD; there are attractions, accessibility, amenities, available packages, activities, and ancillary services.

3) Priority weight

The priority weight referred to in this study is the same as the weight of interest possessed by each criterion. This weight uses a scale of 1 to 5 .

\section{RESUlt AND DiscUSSION}

Two steps are guaranteed to get the results of the research. First, define the components scores of the 6AsTD framework as the criteria score of the TOPSIS method. The second step is to perform the TOPSIS process to get the priority result.

\section{A. 6AsTD Component Scoring}

The selection of tourism destinations requires parameter scores derived from the components of the 6AsTD framework. To get the score of each component, we surveyed 11 popular tourism destinations in Batu City. The survey of 6AsTD framework components carried out by :

- Go to tourism destinations and record all available attraction spots, facilities and services provided in ea tourism destination.

- Retrieve facilities and services data through the analysis of website content owned by tourism destinations.

Based on the survey result of Batu City tourism destinations, all of the components have scores that shown through the following tables.

TABLE I. ATtRACTIONS SCORES

\begin{tabular}{|l|c|c|c|c|r|}
\hline \multirow{2}{*}{$\begin{array}{c}\text { Tourism } \\
\text { Destinations }\end{array}$} & \multicolumn{4}{|c|}{ Attractions Variables } & $\begin{array}{c}\boldsymbol{A} \boldsymbol{1} \\
\text { Score }\end{array}$ \\
\cline { 2 - 5 } & $\boldsymbol{A 1}_{\boldsymbol{1}}$ & $\boldsymbol{A 1}_{\boldsymbol{2}}$ & $\boldsymbol{A 1}_{\boldsymbol{3}}$ & $\boldsymbol{A 1}_{\boldsymbol{4}}$ & \\
\hline Cangar & 2 & 3 & 0 & 0 & 5 \\
\hline Coban Talun & 2 & 5 & 0 & 4 & 11 \\
\hline Selecta & 1 & 6 & 0 & 0 & 7 \\
\hline Alun-alun & 1 & 5 & 0 & 0 & 6 \\
\hline Museum Angkut & 0 & 13 & 0 & 8 & 21 \\
\hline Coban Rais & 4 & 6 & 2 & 0 & 12 \\
\hline Jatim Park 1 & 1 & 12 & 1 & 5 & 19 \\
\hline Jatim Park 2 & 0 & 4 & 0 & 0 & 4 \\
\hline Eco Green Park & 2 & 30 & 0 & 1 & 33 \\
\hline BNS & 0 & 35 & 0 & 1 & 36 \\
\hline Jatim Park 3 & 1 & 13 & 0 & 0 & 14 \\
\hline
\end{tabular}

TABLE II. SCORE OF ACCESSIBILITY COMPONENT

\begin{tabular}{|l|c|c|c|c|r|}
\hline \multirow{2}{*}{$\begin{array}{c}\text { Tourism } \\
\text { Destinations }\end{array}$} & \multicolumn{4}{|c|}{ Accessibility Variables } & \multirow{2}{*}{$\begin{array}{c}\boldsymbol{A 2} \\
\text { Score }\end{array}$} \\
\cline { 2 - 5 } & $\boldsymbol{A 2}_{\boldsymbol{1}}$ & $\boldsymbol{A 2}_{\mathbf{2}}$ & $\boldsymbol{A 2}_{3}$ & $\boldsymbol{A 2}_{\boldsymbol{4}}$ & \\
\hline Cangar & 0 & 3 & 1 & 0 & 4 \\
\hline Coban Talun & 0 & 5 & 1 & 2 & 8 \\
\hline Selecta & 1 & 4 & 0 & 4 & 9 \\
\hline Alun-alun & 0 & 5 & 1 & 4 & 10 \\
\hline Museum Angkut & 1 & 5 & 1 & 5 & 12 \\
\hline Coban Rais & 0 & 2 & 1 & 2 & 5 \\
\hline Jatim Park 1 & 1 & 4 & 2 & 5 & 12 \\
\hline Jatim Park 2 & 1 & 2 & 2 & 5 & 10 \\
\hline Eco Green Park & 3 & 2 & 1 & 4 & 10 \\
\hline BNS & 0 & 7 & 1 & 4 & 12 \\
\hline Jatim Park 3 & 1 & 5 & 2 & 4 & 12 \\
\hline
\end{tabular}


TABLE III. SCORE OF AMENITIES COMPONENT

\begin{tabular}{|l|c|c|c|c|r|}
\hline \multirow{2}{*}{$\begin{array}{c}\text { Tourism } \\
\text { Destinations }\end{array}$} & \multicolumn{4}{|c|}{ Amenities Variables } & \multirow{2}{*}{$\begin{array}{c}\boldsymbol{A 3} \\
\text { Score }\end{array}$} \\
\cline { 2 - 5 } & $\boldsymbol{A 3}_{\boldsymbol{1}}$ & $\boldsymbol{A 3}_{2}$ & $\boldsymbol{A 3}_{3}$ & $\boldsymbol{A 3}_{\boldsymbol{4}}$ & \\
\hline Cangar & 0 & 1 & 4 & 0 & 5 \\
\hline Coban Talun & 0 & 1 & 4 & 0 & 5 \\
\hline Selecta & 2 & 4 & 7 & 2 & 15 \\
\hline Alun-alun & 5 & 5 & 5 & 9 & 24 \\
\hline Museum Angkut & 4 & 4 & 14 & 7 & 29 \\
\hline Coban Rais & 1 & 3 & 3 & 0 & 7 \\
\hline Jatim Park 1 & 3 & 7 & 12 & 3 & 25 \\
\hline Jatim Park 2 & 4 & 4 & 7 & 3 & 18 \\
\hline Eco Green Park & 3 & 4 & 8 & 2 & 17 \\
\hline BNS & 2 & 4 & 9 & 2 & 17 \\
\hline Jatim Park 3 & 4 & 4 & 4 & 1 & 13 \\
\hline
\end{tabular}

TABLE IV. Score of AVAliable PaCKages AND ACtivities COMPONENT

\begin{tabular}{|l|r|r|}
\hline \multirow{2}{*}{$\begin{array}{c}\text { Tourism } \\
\text { Destinations }\end{array}$} & \multicolumn{2}{|c|}{$\begin{array}{c}\text { Components } \\
\text { Scores }\end{array}$} \\
\cline { 2 - 3 } & $\boldsymbol{A 4}$ & \multicolumn{1}{c|}{$\boldsymbol{A 5}$} \\
\hline Cangar & 1 & 4 \\
\hline Coban Talun & 1 & 3 \\
\hline Selecta & 1 & 7 \\
\hline Alun-alun & 2 & 3 \\
\hline Museum Angkut & 2 & 6 \\
\hline Coban Rais & 1 & 3 \\
\hline Jatim Park 1 & 5 & 5 \\
\hline Jatim Park 2 & 2 & 6 \\
\hline Eco Green Park & 1 & 5 \\
\hline BNS & 2 & 3 \\
\hline Jatim Park 3 & 2 & 5 \\
\hline
\end{tabular}

TABLE V. SCORE OF ANCILLARY COMPONENT

\begin{tabular}{|l|c|c|c|c|c|r|}
\hline \multirow{2}{*}{$\begin{array}{c}\text { Tourism } \\
\text { Destinations }\end{array}$} & \multicolumn{5}{|c|}{ Ancillary Services Variables } & \multirow{2}{*}{$\begin{array}{c}\boldsymbol{A 6} \\
\text { Score }\end{array}$} \\
\cline { 2 - 6 } & $\boldsymbol{A 6}_{\boldsymbol{1}}$ & $\boldsymbol{A 6}_{\mathbf{2}}$ & $\boldsymbol{A 6}_{\boldsymbol{3}}$ & $\boldsymbol{A 6}_{\boldsymbol{4}}$ & $\boldsymbol{A 6}_{\boldsymbol{5}}$ & \\
\hline Cangar & 0 & 1 & 0 & 1 & 0 & 2 \\
\hline Coban Talun & 0 & 1 & 0 & 1 & 1 & 3 \\
\hline Selecta & 0 & 1 & 0 & 3 & 2 & 6 \\
\hline Alun-alun & 4 & 4 & 3 & 3 & 2 & 16 \\
\hline Museum Angkut & 4 & 2 & 3 & 3 & 2 & 14 \\
\hline Coban Rais & 0 & 2 & 0 & 2 & 1 & 5 \\
\hline Jatim Park 1 & 2 & 3 & 4 & 3 & 2 & 14 \\
\hline Jatim Park 2 & 2 & 3 & 4 & 3 & 2 & 14 \\
\hline Eco Green Park & 3 & 3 & 1 & 3 & 2 & 12 \\
\hline BNS & 2 & 2 & 1 & 3 & 2 & 10 \\
\hline Jatim Park 3 & 3 & 1 & 0 & 3 & 2 & 9 \\
\hline
\end{tabular}

Table 1 describes the results of attractions component scoring. This score represents the number of available tourist spots based on the natural landscape, artificial tourism, cultural tourism, and special events. BNS has the highest score, while the lowest is Jatim Park 2. It shows that BNS had a more interesting tourism spot than other tourism destinations in Batu. Table 2 shows the results of the accessibility component assessment. This score is obtained by considering the four variables that belong to the accessibility component. The table also describes the assessment of transportation routes and facilities that can be used to reach tourism destinations. Table 3 shows the results of the amenities evaluation. The table also shows the completeness of supporting facilities that are directly related to tourism activities, for example, the availability of lodging, restaurants, shopping centers and public facilities provided at the tourism destinations area. In this component, Museum Angkut, Jatim Park 1, and Alun-Alun have the highest score.

Table 4 illustrates the difference score of available tour packages owned by available packages components. Every tourism destinations in Batu city generally already have a tour package that is offered by the management or by travel agents. However, the variation of packages is different, so it assesses available packages also becomes unequal. Table 4 also describes a variety of activities that visitors can do. Each tourism destination has a more evenly distributed score of activity components. This score indicates that the destinations have almost the same score. Table 5 shows the completeness of supporting facilities in the tourism destinations that are not directly related to tourism activities. Jatim Park 1 is the complete tourism destination compared to the others.

\section{B. TOPSIS Implementations Result}

Table 6 shows the scores of 6AsTD framework components as the criteria for selecting priorities. Each component has a different weight, as shown in Table 7. The components of accessibility, amenities, and activities have the highest weight because the three components are directly related to the convenience of tourism activities. The table shows that available packages weight 4 , and the ancillary service weights 3 . Attractions have the least weight because the development of the components of the attraction limited by the initial theme of the tourism destinations.

TABLE VI. THE SCORES OF 6ASTD COMPONENTS AS THE TOPSIS CRITERIA

\begin{tabular}{|l|c|c|c|c|c|c|}
\hline \multirow{2}{*}{$\begin{array}{c}\text { Tourism } \\
\text { Destinations }\end{array}$} & \multicolumn{7}{|c|}{ 6AsTD Component } \\
\cline { 2 - 8 } & $\boldsymbol{A 1}$ & $\boldsymbol{A 2}$ & $\boldsymbol{A 3}$ & $\boldsymbol{A 4}$ & $\boldsymbol{A 5}$ & $\boldsymbol{A 6}$ \\
\hline Cangar & 5 & 4 & 5 & 1 & 4 & 2 \\
\hline Coban Talun & 11 & 8 & 5 & 1 & 3 & 3 \\
\hline Selecta & 7 & 9 & 15 & 1 & 7 & 6 \\
\hline Alun-alun & 6 & 10 & 24 & 2 & 3 & 16 \\
\hline Museum Angkut & 21 & 12 & 29 & 2 & 6 & 14 \\
\hline Coban Rais & 12 & 5 & 7 & 1 & 3 & 5 \\
\hline Jatim Park 1 & 19 & 12 & 25 & 5 & 5 & 14 \\
\hline Jatim Park 2 & 4 & 10 & 18 & 2 & 6 & 14 \\
\hline Eco Green Park & 33 & 10 & 17 & 1 & 5 & 12 \\
\hline BNS & 36 & 12 & 17 & 2 & 3 & 10 \\
\hline Jatim Park 3 & 14 & 12 & 13 & 2 & 5 & 9 \\
\hline
\end{tabular}

TABLE VII. PRIORITY WEIGHTING OF 6ASTD COMPONENT

\begin{tabular}{|l|c|}
\hline \multicolumn{1}{|c|}{ 6AsTD Component } & $\begin{array}{c}\text { Priority } \\
\text { Weighting }\end{array}$ \\
\hline Attractions $(A 1)$ & 2 \\
\hline Accessibility $(A 2)$ & 5 \\
\hline Amenities $(A 3)$ & 5 \\
\hline Available Packages $(A 4)$ & 4 \\
\hline Activities $(A 5)$ & 5 \\
\hline Ancillary Service $(A 6)$ & 3 \\
\hline
\end{tabular}




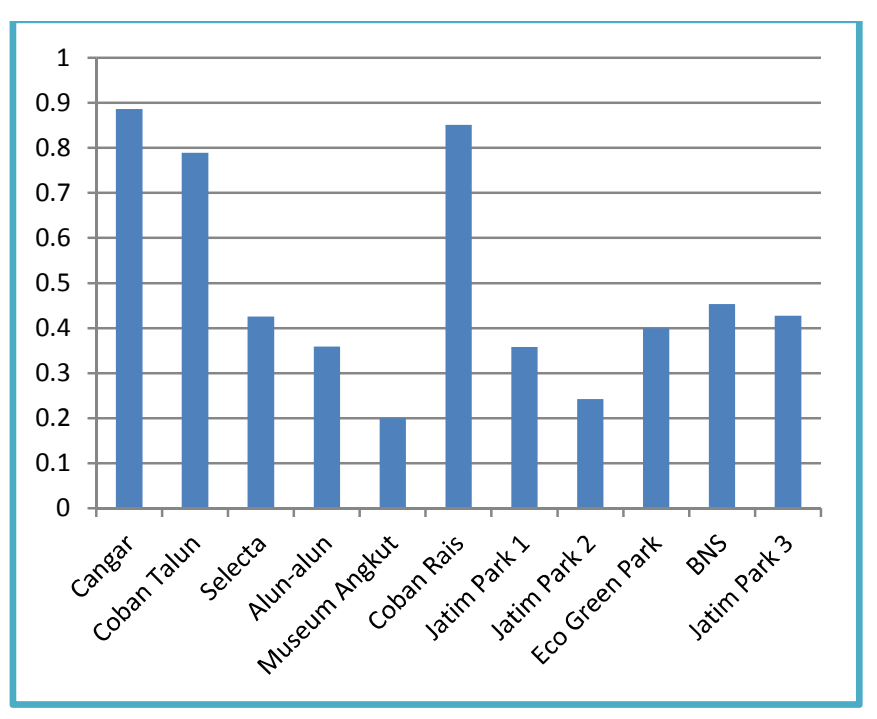

Figure 14: The score of priority for developing tourism destinations

Figure 14 shows the ranking results of prioritizing tourist destinations using TOPSIS. Based on these figures, destinations with the highest score also has the highest priority than others. Cangar was ranked first in the priority of tourism development, followed by CobanRais and CobanTalun. Cangar has a score of 0.88 , while CobanRais is 0.85 , and CobanTalun is 0.78. Tourism destination in Batu City, which has the lowest development priority, is Museum Angkut with a score of 0.19 .

\section{CONCLUSIONS}

The development of tourism destinations, especially in developing countries, requires accuracy in determining the destination priority. This research offers a concept in prioritizing the development of tourist destinations by combining the 6AsTD framework and the TOPSIS method. Each component of the framework has variables with different scores and characteristics. The components scores illustrate the success level of tourism destinations as the TOPSIS criteria. We use the TOPSIS method to select the priority of tourism destination development. Based on the process results of 11 tourism destinations in Batu City, Cangar has top priority with the highest score, followed by CobanRais, CobanTalun, BNS, Jatim Park 3, Selecta, Eco Green Park, Alun-Alun, Jatim Park 1, Jatim Park 2 and the last is BNS.

\section{ACKNOWLEDGMENT}

This research supported by the Telematic Engineering Laboratory of Institut Teknologi Sepuluh November Surabaya and Multimedia Laboratory of Universitas Islam Negeri Maulana Malik Ibrahim Malang.

\section{REFERENCES}

[1] P. J. Cárdenas-García, M. Sánchez-Rivero, and J. I. Pulido-Fernández, "Does Tourism Growth Influence Economic Development?," J. Travel Res., vol. 54, no. 2, pp. 206-221, 2015.

[2] D. Buhalis and A. Amaranggana, "Smart Tourism Destinations," Inf. Commun. Technol. Tour. 2014, pp. 553-564, 2014.

[3] A. Presenza, "the Performance of a Tourism Destination. Who Manages the Destination? Who
Plays the Audit Role?," Soc. Sci., no. February, pp. 114, 2016.

[4] L. Medeiros, C. Falcão de Oliveira, and C. Rezende, "Competitiveness of tourist destinations: the study of 65 key destinations for the development of regional tourism," Rev. Adm. Pública, vol. 44, no. 5, pp. 10671095, 2010.

[5] I. Ebrahimzadeh, "Analysis of Tourism Facilities' Distribution and its Optimization Based upon Ashworth-Tunbridge and Getz Models Using GIS; Case Study: Semnan in Historical Silk Route," Humanity. Soc. Sci., vol. 2, no. 3, p. 47, 2014.

[6] Ontario's Highlands Tourism Organization, "Premier Ranked Tourist Destination Framework." 2011.

[7] D. Buhalis, "Buhalis Marketing the competitive destination of the future," Tour. Manag., vol. 21, no. January 1999, pp. 97-116, 2000.

[8] W. Put-van den Beemt and R. Smith, "Smart tourism tools: linking technology to the touristic resources of a city," Smart Tour. Congr. Barcelona, pp. 1-12, 2016.

[9] G. S. Da, "Selection of a Communication Satellite Manufacturer using MCDM methods," pp. 347-351, 2015.

[10] M. Tavana and A. Hatami-Marbini, “A group AHPTOPSIS framework for human spaceflight mission planning at NASA," Expert Syst. Appl., vol. 38, no. 11, pp. 13588-13603, 2011.

[11] Z. U. Rehman, O. K. Hussain, and F. K. Hussain, "Iaas cloud selection using MCDM methods," Proc. - 9th IEEE Int. Conf. E-bus. Eng. ICEBE 2012, pp. 246$251,2012$.

[12] C. Lamsfus, D. Martin, and A. Alzua-Sorzabal, "Smart Tourism Destinations: An Extended Conception of Smart Cities Focusing on Human Mobility," Inf. Commun. Technol. Tour. 2015, pp. 363-375, 2015.

[13] C. Koo, S. Shin, U. Gretzel, W. C. Hunter, and N. Chung, "Conceptualization of Smart Tourism Destination Competitiveness," Asia Pacific J. Inf. Syst., vol. 26, no. 4, pp. 561-576, 2016.

[14] S. Vengesayi, F. T. Mavondo, and Y. Reisinger, "Tourism Destination Attractiveness: Attractions, Facilities, and People as Predictors," Tour. Anal., vol. 14, no. 5, pp. 621-636, 2009.

[15] S. Harman, "Importance of Destination Attributes Affecting Destination Choice of," Education, pp. 131145, 2007.

[16] H. M. Tran, A. Huertas, and A. Moreno, "(SA)6: A new framework for the analysis of smart tourism destinations. A comparative case study of two Spanish destinations," Congr. - Semin. Destin. Tur. Intel. 2017 - Libr. Actas, vol. 320470350, no. February 2018, pp. 190-214, 2017.

[17] F. Kurniawan, A. P. Wibawa, Munir, S. M. S. Nugroho, and M. Hariadi, "Makassar smart city operation center priority optimization using fuzzy multi-criteria decision-making," Int. Conf. Electr. Eng. Comput. Sci. Informatics, vol. 4, no. September, pp. 289-293, 2017.

[18] X. Xie, Q. Zhu, and Z. Chang, "Performance evaluation of automobile ASPs using TOPSIS," Proc. 2013 4th Int. Conf. Digit. Manuf. Autom. ICDMA 2013, pp. 910-913, 2013. 
[19] E. Roszkowska, "Multi-criteria decision making models by applying the TOPSIS method to crisp and interval data," Mult. Criteria Decis. Mak., vol. 6, no. Mcdm, pp. 200-230, 2011.

[20] S. Kaur, S. K. Sehra, and S. S. Sehra, "A framework or software quality model selection using TOPSIS," 2016 IEEE Int. Conf. Recent Trends Electron. Inf. Commun. Technol. RTEICT 2016 - Proc., pp. 736-739, 2017. 